\title{
In situ gamma radiation measurements in the Neoproterozoic rocks of Sirohi region, NW India
}

\author{
Lars Scharfenberg $^{1, *}$, Helga De Wall ${ }^{1}$, Stefan Schöbel $^{1}$, Alexander Minor ${ }^{1}$, \\ Marcel Maurer ${ }^{1}$, Manoj K Pandit ${ }^{2}$ and Kamal K Sharma ${ }^{3}$ \\ ${ }^{1}$ GeoZentrum Nordbayern, Universität Erlangen-Nürnberg, Schlossgarten 5, D-91054 Erlangen, Germany. \\ ${ }^{2}$ Department of Geology, University of Rajasthan, Jaipur 302 004, India. \\ ${ }^{3}$ Department of Geology, Government Postgraduate College, Sirohi 307 001, India. \\ *Corresponding author.e-mail: lars.scharfenberg@fau.de
}

Natural gamma ray measurements using a portable device were performed at 157 sites in the area around Sirohi town and Sindreth village in Rajasthan (NW India). This region comprises sedimentary rocks, metasediments, granites and gneisses that bear characteristic GR dose values and U/Th ratios corresponding with their specific geological history. A-type Malani granites and rhyolitic derivates, also referred as high heat production granites, show distinct differences as compared to the S-type Erinpura and Balda granites, most prominent in a high Th content of the former (up to $90 \mathrm{ppm}$ ). Sedimentary rocks in the Sirohi and Sindreth area are variable in their signatures reflecting their variable source rocks. In the area between the Balda and Paladi villages, northeast of Sirohi, measurements in vicinity of a N-S running shear zone, have shown U enrichment up to $8 \mathrm{ppm}$. This shear zone has been synkinematically mineralized with quartz and shows evidence of fluid infiltration into the host rocks in the vicinity of the shear zone. Erinpura granites have been altered due to fluid activity and show a light depletion of $\mathrm{K}$ $(3.96 \%)$ and Th (20.11 ppm) as compared to the unaltered rocks (K, 4.06; Th $24.46 \mathrm{ppm})$. Enrichment of $\mathrm{U}$ (with a mean value of $13 \mathrm{ppm}$ ) has also been recorded in the lower clastic unit of the Sindreth Basin, especially within gritty conglomerates wherein migration and precipitation along fault planes is proposed.

\section{Introduction}

The role of natural gamma ray (GR) spectroscopy as a reliable tool in lithologic characterization and evaluation of elemental mobility has been underlined in a number of recent studies based on natural gamma-ray mapping. Studies, such as the airborne survey for large-scale aerial mapping of remote areas (e.g., El-Sadek 2002; Asfahani et al. 2012), petrochemical mapping (Aydin et al. 2006), fieldbased mapping of rock-exposures in basement and sedimentary rocks (e.g., Tzortzis et al. 2003) and soil cover (Bellotti et al. 2007) can be cited as examples of application of this method in a wide array of geologic conditions. Anomalies in natural radiation have been commonly used in exploration surveys (e.g., Kovačević et al. 2009, 2013). Radiation is produced by the decay of natural radioactive isotopes of $\mathrm{K}$, U, Th that are generally concentrated in crustal rocks. Rock-forming silicates, such as feldspar and mica, are the major hosts of $\mathrm{K}$, while $\mathrm{U}$ and $\mathrm{Th}$ are preferentially incorporated in accessory minerals such as zircon, monazite, allanite or xenotime. Primarily formed from crystallization of felsic magmas, such minerals are also present in notable concentrations in their metamorphic derivatives (granite-gneisses) and in clastic sediments on account of their stability under

Keywords. Gamma ray spectrometry; Neoproterozoic; uranium; Sirohi; Sindreth; NW India. 
low to medium grade metamorphism and resistance to weathering.

A number of felsic magmatic bodies, related to different episodes of Proterozoic acid magmatism, occur around the town of Sirohi, in the western foreland of the Delhi Fold Belt in NW India, the target area of this reconnaissance GR study (figures 1 and 2). Granitic rocks in this region can be broadly subdivided into two temporal settings, the 870-800 Ma Erinpura Granite and 770-750 Ma Malani Igneous Suite (MIS; Deb et al. 2001; Gregory et al. 2009; Just et al. 2011). These rock suites show diverse petrogenetic and emplacement histories, clearly reflected in distinct differences in their chemical characteristics (Naik 1993; de Wall et al. 2012 , 2014). In addition to granitoids, we have also surveyed metasediments and volcanics of the Sirohi and Sindreth Group rocks. The Sindreth
Basin is a narrow linear sedimentary basin located to the south-west of Sirohi town (figures 1 and 2).

The Sirohi region represents large scale faults and shear zones (Just et al. 2011; Pandit et al. 2011; de Wall et al. 2012, 2014) that may have served as pathways for crustal fluids that are supposed to have caused enrichment or depletion of radiogenic elements. Locally elevated levels of uranium-related radioactivity were recently reported from Sindreth Group, by Somani et al. (2012). In this paper, we present the preliminary GR data on the Sirohi-Sindreth region. The GR spectral results for $\mathrm{U}$, Th and $\mathrm{K}$ have been evaluated and interpreted in terms of primary (protolith-related) and secondary (related to redeposition, faulting and shearing) events in the Neoproterozoic geological history of this region.

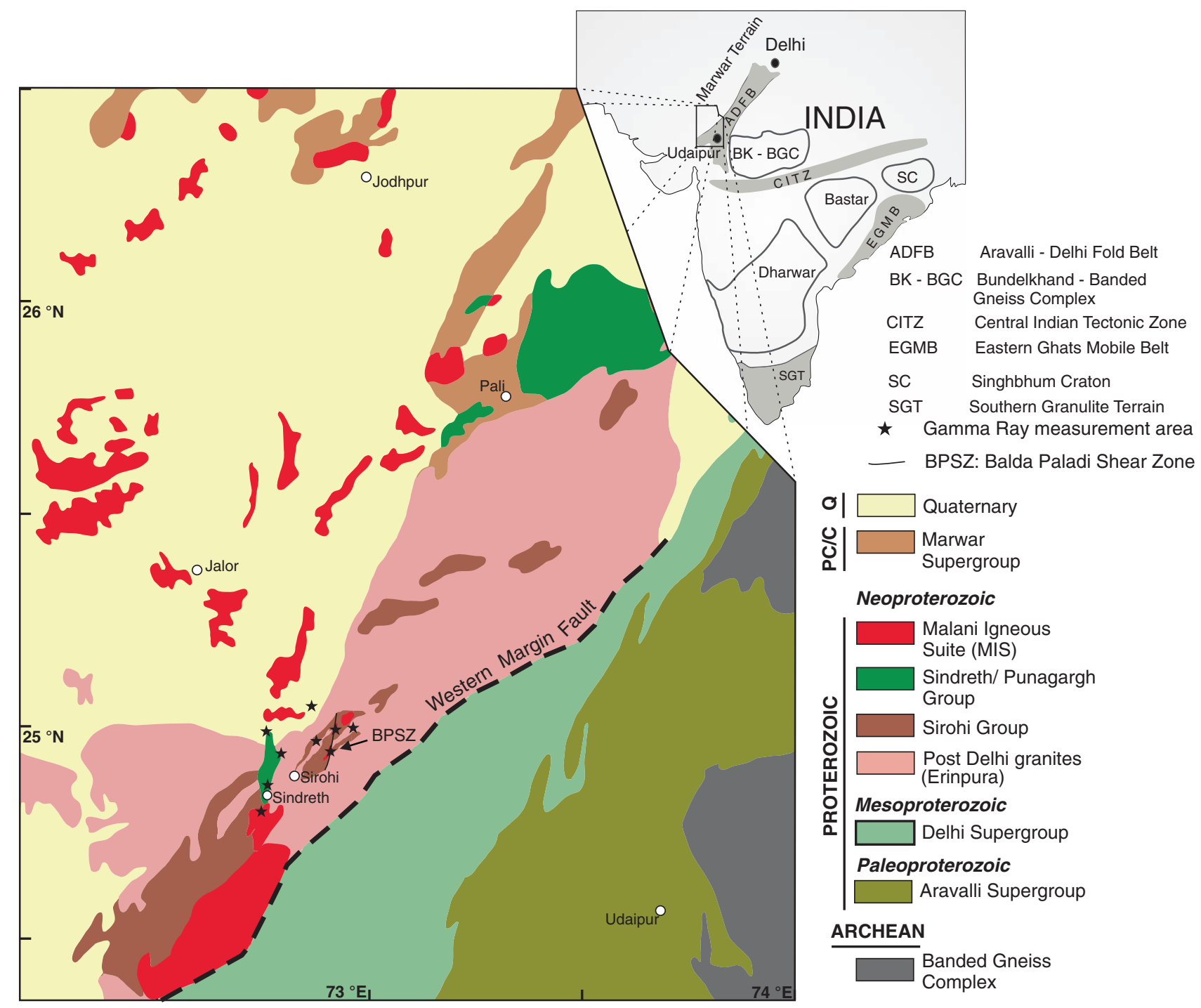

Figure 1. Simplified lithostratigraphic map of the Aravalli-Delhi Fold Belt (adapted from Gupta et al. 1997) within the tectonic framework of NW India and inset map, showing Precambrian cratons and orogenic belts of India. The box marks the study area. 


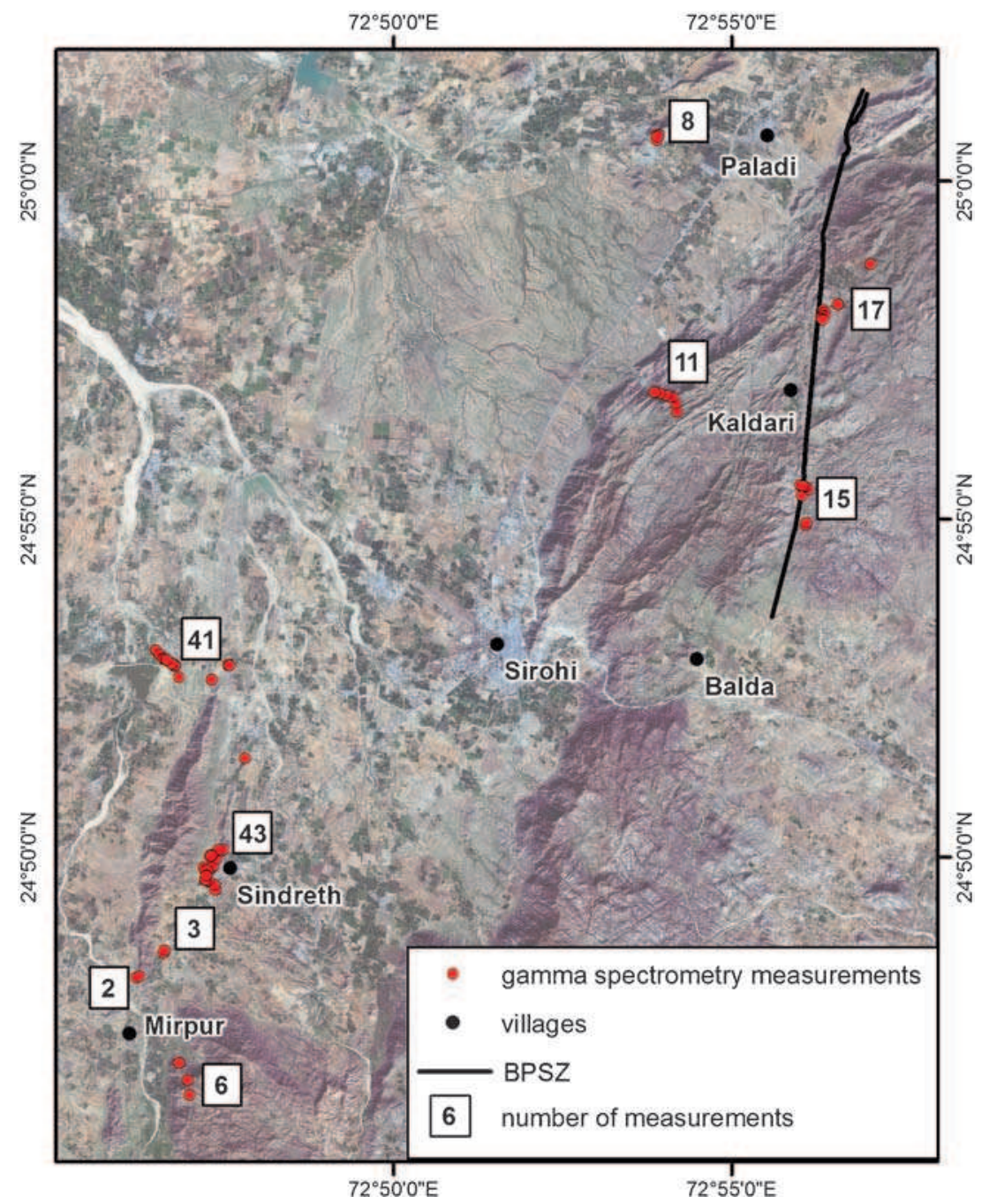

Figure 2. Location of in situ measurements in the Sirohi-Sindreth region shown on a pan-sharpened normal colour LandSat 8 image (courtesy: US Geological Survey).

\section{Geological setting}

Sirohi region comprises NE-trending ridges formed by Neoproterozoic metasediments and granitegneisses in the eastern part and a peneplained terrain in the west. Sirohi town is situated at the south-western culmination of two subparallel hills and along the western flank. Another NE-trending hill located to the south of Sindreth village, the Mirpur (granite) hill, extends southward and forms a part of the Mount Abu mountain system. A narrow linear system of almost $\mathrm{N}-\mathrm{S}$ trending ridges is located to the west of Sirohi town and defines the Sindreth Basin. The region, further west, forms the eastern limits of the vast Thar Desert in the peneplained Marwar terrain.

NW India is constituted by two tectonic blocks, the Marwar terrane in the west and the AravalliBundelkhand Craton in the east, both amalgamated at $\sim 1$ Ga during the Delhi Orogeny (Bhowmik et al. 2010; Meert et al. 2010 and references therein). The collision zone is prominent along the western margin of the linear, NE-SW trending Delhi Fold Belt (DFB; figure 1). Several NE-SW trending granitic intrusions in this region have been ascribed to the end-orogenic processes of the Delhi deformation (e.g., Gupta et al. 1997). These late-stage granitic intrusions, broadly characterized as S-type granites, are collectively termed as 'Erinpura Granite' (Heron 1953) that often show a gneissic fabric. Geochronological studies (Deb et al. 2001; van Lente et al. 2009) have shown that Erinpura Granite intrusions span between 870 and 800 Ma. Sediments of the Sirohi Group (carbonates, marls, pelites; Sharma 1996; Roy and Sharma 1999) were deposited following the uplift of the Erinpura Granite terrain (de Wall et al. 2014). Crustal convergence during Cryogenian period, initiated folding and thrusting, metamorphism of sediment up to lower greenschist facies and intrusion of the leucocratic Balda Granite (de Wall et al. 2014). The Sirohi hills 
define a NE-SW trending about $20 \mathrm{~km}$ long, eyeshaped structure with a maximum width of $6 \mathrm{~km}$. Deformation in the Sirohi region has been constrained at $770 \mathrm{Ma}$ (Just et al. 2011) overlapping with the timing of $\sim 770-750 \mathrm{Ma}$, Malani magmatism, the third largest felsic magmatic province in the world (Kochhar 1989; Bhushan 2000) spread over an area of $>50,000 \mathrm{~km}^{2}$ in NW India. The Malani Igneous Suite (MIS) comprises predominantly felsic plutonic and volcanic rocks and dykes. Mirpur Granite and various rhyolitic dykes represent the MIS rocks in this region. Small, linear basins (e.g., the Sindreth Basin) were developed coevally with MIS along a linear structure west of the deformed Sirohi metasediments (Sharma 1996, 2004; van Lente et al. 2009). Basin infills include clastic sediments derived from the Sirohi metasediments, the Erinpura Granite-gneisses and the Mirpur Granite, intercalated with bimodal volcanics (Chore and Mohanty 1998). Supra-crustal fault systems were developed during the basin inversion.

In summary, the region around Sirohi comprises variably deformed to visibly undeformed and metamorphosed sediments, volcaniclastics, tuffs and mafic and felsic lava flows. These rocks are expected to contain variable concentrations of radioactive elements, therefore, suitable for mapping the natural gamma-ray activity.

\section{Methodology}

Gamma radiations were recorded with the help of a portable gamma ray spectrometer RS 230 manufactured by Radiation Solutions, Ontario, Canada. It uses a Bismuth Germanate (BGO) detector that, on account of higher material density, is about $50 \%$ more precise than portable units using a sodium iodide (NaI) detector with a crystal of the same size. Due to its small size (25 cm long, $10 \mathrm{~cm}$ wide) and light weight $(2 \mathrm{~kg})$, it is easy to carry and use in the field. Gamma rays cause light flashes in the BGO scintillation crystal that are transformed into electrical impulses in a photomultiplier tube. These impulses and their strength are registered in the device. The daughter elements of uranium, potassium and thorium produce characteristic energy peaks in the resulting radiation spectra that are automatically used by the spectrometer to estimate the concentration of radioactive elements. Measurements were taken in the 'Assay-mode', which means a single measurement for estimation of thorium and uranium (in ppm) and potassium (weight $\%$ ) from the spectrum of gamma radiation measured over a certain time interval. Coordinates of sites for $\gamma$-radiation measurements were recorded using a GPS connected to the spectrometer via bluetooth. The instrument is also useful for quick scanning of the total $\gamma$-radiation count of rocks, which is studied in its 'survey mode'.

A measuring interval of $120 \mathrm{~s}$ was maintained to allow sufficient time for calibration. The device integrates an area of about $1 \mathrm{~m}$ diameter with a depth of about $25 \mathrm{~cm}$ when in direct contact with the outcrop (IAEA 2003).

The values used for stripping and background correction were provided by the manufacturer of the device and are stored and applied in the spectrometer unit itself. Transportable concrete pads of $1 \mathrm{~m} \times 1 \mathrm{~m} \times 30 \mathrm{~cm}$ size containing known amounts of potassium, uranium and thorium and a fourth pad with none of these three elements to measure the background as described in Grasty et al. (1991) were used by Radiation Solutions to obtain the stripping ratios and sensitivity constants for the matrix calculations that are carried out inside the spectrometer for background correction and conversion to ppm (for $\mathrm{U}$ and $\mathrm{Th}$ ) and \% (for potassium). The sources of error that can occur, according to Radiation Solutions Inc. (2007), are statistical errors due to noise of the counting, that can be reduced by choosing longer counting times; calibration errors that become comparable to the statistical error if the counting time is extended above 2 min and if levels of $\mathrm{K}, \mathrm{U}$ and Th exceed the calibration pad concentrations of $4 \% \mathrm{~K}, 25 \mathrm{ppm} \mathrm{U}$ and $70 \mathrm{ppm} \mathrm{Th}$; a geometrical error, because the detector assumes a homogeneous half-space of material, which is almost never the case in nature, and errors due to the counting

Table 1. Expected errors for particular concentrations of $K$, U, Th at the Sigma level (Radiation Solutions Inc. 2007).

\begin{tabular}{lccc}
\hline & $\begin{array}{c}\text { 1 Sigma } \\
\text { K }(\%)\end{array}$ & $\begin{array}{c}\text { 1 Sigma } \\
\text { U }(\mathrm{ppm})\end{array}$ & $\begin{array}{c}1 \text { Sigma } \\
\text { Th }(\mathrm{ppm})\end{array}$ \\
\hline Content K (\%) & & & \\
0.1 & 0.030 & 0.041 & 0.006 \\
1 & 0.096 & 0.130 & 0.019 \\
5 & 0.214 & 0.291 & 0.042 \\
10 & 0.303 & 0.412 & 0.060 \\
& & & \\
Content U (ppm) & & & \\
1 & 0.043 & 0.307 & 0.027 \\
10 & 0.135 & 0.970 & 0.087 \\
100 & 0.427 & 3.067 & 0.274 \\
1000 & 1.349 & 9.698 & 0.866 \\
10,000 & 4.27 & 30.67 & 2.74 \\
& & & \\
Content Th (ppm) & & & \\
1 & & & \\
10 & 0.023 & 0.237 & 1.705 \\
100 & 0.072 & 0.750 & 5.391 \\
1000 & 0.228 & 2.373 & 53.9 \\
10,000 & 0.721 & 7.504 & \\
\hline
\end{tabular}


time which depend on the level of radiation in the measured area. Expected errors for particular concentrations of K, U and Th at the 1 Sigma level are noted in table 1 (Radiation Solutions Inc. 2007).

According to Radiation Solutions Inc. (2007) and Grasty et al. (1991) cross-interference needs to be taken into account as well, because for varying concentrations of one element, there are not only error components for that element but also for the remaining elements. The error needs to be calculated by taking the square root of the sum of the square of errors. For example, at a concentration of $1 \% \mathrm{~K}, 10 \mathrm{ppm} \mathrm{U}$ and $10 \mathrm{ppm}$ Th, the combined $\mathrm{K}$-error is $\mathrm{SQRT}(0.096 * 0.096+0.135 * 0.135+$ $0.072+0.072)=0.18$.

\section{Results}

\subsection{GR characteristics of rock units}

As stated earlier, three distinct geological domains, namely granitoids and metasediments of Sirohi region and Sindreth Basin rocks were subjected to radiometric analysis. The radiometric characteristics are mentioned below.

Granitoids of the Sirohi region show distinct differences in GR activity and spectra (table 2). The following mean values for rock units represent the radiation dose detected by the measurement device, recorded in $\mathrm{nSv} / \mathrm{h}$. Calculated concentrations of the radio elements are given in ppm. Mirpur Granite (310 nSv/h) and Sindreth rhyolite $(298 \mathrm{nSv} / \mathrm{h})$ show distinctly higher radiation as compared to Erinpura (177.11 nSv/h) and Balda (180.95 nSv/h) granites. Mean K values range between 4 and 5\% (values typical for granites) and do not show significant differences among the individual granitoids. Instead, U and Th contents are variable between the granitoids: the U content is lower in the Erinpura (4.12 ppm) and Balda (5.84 ppm) granites as compared to 8.06 and $6.52 \mathrm{ppm}$ for the MIS rocks (Mirpur Granite and rhyolites, respectively). The latter ones are characterized by distinctly higher Th content with values up to $76 \mathrm{ppm}$ near the type locality at Mirpur village, and up to $42 \mathrm{ppm}$ in the Sindreth area, nearly twice as high or even three times as high (at Mirpur) as the other granitoids (24 ppm).

Metasediments of the Sirohi Group comprise carbonates, calc-silicates and phyllites. Some of the phyllites are carbonaceous (carbon phyllites), therefore likely to show higher levels of natural radiation as U-minerals such as uraninite are reported from various localities of carbon phyllites in NW India (Purohit et al. 2012). Sirohi metasediments, in general, show significantly lower average in GR activity (101.26 nSv/h) as compared to the granites. However, values for individual samples are highly variable (26.6-146.4 nSv/h). Quarzite and psammites have recorded the lowest GR activity $(27 \mathrm{nSv} / \mathrm{h})$, carbonates reach up to $72 \mathrm{nSv} / \mathrm{h}$, while carbonaceous phyllites have recorded the highest values up to $146.4 \mathrm{nSv} / \mathrm{h}$. U content is also low with an average of $6.08 \mathrm{ppm}$ but can reach up to $10 \mathrm{ppm}$ in individual bands/layers of carbon phyllite.

In the Sindreth Basin, the coarse-grained, lower and upper clastic units, separated by the mafic and felsic lava flows, show clear differences in GR values. The upper clastic unit is characterized by slightly higher GR activity, most likely related to higher Th content $(18.22 \mathrm{ppm})$ compared to the lower clastic unit (12.46 ppm). This is also reflected in the distinct difference in $\mathrm{U} / \mathrm{Th}$ ratios of 0.45 and 0.13 , respectively. Such a variation in GR signatures in clastic rocks indicates changes in the provenance which has been evaluated in a separate study by our research group. The volcanic units are characterized by strongly variable values, very high in the rhyolite $(298 \mathrm{nSv} / \mathrm{h})$ intermediate in the felsic tuffs $(80 \mathrm{nSv} / \mathrm{h})$ and lowest in the basalts $(19.26 \mathrm{nSv} / \mathrm{h})$. A debris flow deposit, named as gritty (sandstone) clastics on account of coarser and variable grain size occurs above the coarse-grained clastics of the lower clastic unit.

Table 2. Mean values and standard deviation of GR data for different rock units in the Sirohi region.

\begin{tabular}{|c|c|c|c|c|c|c|c|c|c|c|}
\hline & $\mathrm{N}$ & Dose (nSv/h) & $\mathrm{K}(\%)$ & Stdv & $\mathrm{U}(\mathrm{ppm})$ & Stdv & Th (ppm) & Stdv & $\mathrm{U} / \mathrm{Th}$ & Stdv \\
\hline Mirpur Granite & 14 & 310.61 & 5.06 & 0.81 & 8.06 & 5.10 & 54.51 & 23.08 & 0.14 & 0.04 \\
\hline Balda Granite & 8 & 180.95 & 4.12 & 0.35 & 5.84 & 3.46 & 23.66 & 20.09 & 0.36 & 0.22 \\
\hline Erinpura Granite & 26 & 175.56 & 4.06 & 1.03 & 4.17 & 1.70 & 24.46 & 6.12 & 0.17 & 0.07 \\
\hline Erinpura-altered & 16 & 163.54 & 3.96 & 1.25 & 5.34 & 1.61 & 20.11 & 6.06 & 0.34 & 0.37 \\
\hline Sirohi Group & 11 & 101.26 & 1.50 & 1.13 & 6.08 & 3.58 & 11.52 & 5.08 & 0.57 & 0.30 \\
\hline \multicolumn{11}{|l|}{ Sindreth: } \\
\hline Lower clastics & 30 & 107.69 & 1.99 & 0.66 & 5.44 & 2.53 & 12.43 & 3.10 & 0.46 & 0.22 \\
\hline Gritty clastics & 10 & 199.66 & 3.46 & 0.59 & 12.96 & 8.19 & 18.29 & 2.33 & 0.72 & 0.48 \\
\hline Upper clastics & 19 & 110.27 & 2.24 & 0.82 & 2.35 & 0.57 & 18.23 & 3.34 & 0.13 & 0.04 \\
\hline Rhyolite & 5 & 298.00 & 4.00 & 1.07 & 6.52 & 1.57 & 59.20 & 9.15 & 0.11 & 0.02 \\
\hline Felsic tuff & 4 & 80.00 & 1.75 & 0.34 & 2.65 & 1.02 & 10.87 & 4.75 & 0.25 & 0.02 \\
\hline Basalts & 5 & 19.26 & 0.54 & 0.48 & 0.40 & 0.31 & 2.44 & 0.13 & 0.17 & 0.13 \\
\hline
\end{tabular}


This unit shows anomalous high radiation values (199.66 nSv/h), related to higher U (12.96 ppm) and $\mathrm{Th}(18.29 \mathrm{ppm})$ contents. Differences in the GR characteristics of Sirohi and Sindreth rock units are best reflected in the $\mathrm{U} v s$. Th and $\mathrm{U} / \mathrm{Th}$ vs. radiation dose plots in figure 3. The highly variable U/Th ratio of Sirohi and Sindreth rocks ranging from $<0.1$ to 1.4 may reflect both primary differences and secondary U remobilization. Comparison of $\mathrm{U} / \mathrm{Th}$ ratios with geochemical data taken from literature, supports the in situ measurements. This comprises $\mathrm{U} / \mathrm{Th}$ ratios of $0.11,0.29,0.27$ for rhyolites, tuffs and basalts of the Sindreth bimodal volcanics (van Lente et al. 2009), 0.2 for the Mirpur granite (Schöbel 2009), 0.43 for the Balda and 0.1 for the Erinpura Granites (de Wall et al. 2014).

\section{$4.2 U$ and Th distribution in the Balda-Paladi Shear Zone}

The N-S trending Balda-Paladi Shear Zone (BPSZ - de Wall et al. 2014), is traceable over a distance of $10 \mathrm{~km}$. It cross-cuts and transects Erinpura Granite and Sirohi metasediments and at places, forms the boundary between the lithounits. In a major part, the BPSZ is mineralized by pure milky quartz which highlights its significance as pathway for large-scale fluid flow (Minor 2013).

Erinpura and Balda granites show features of alterations as a consequence of fluid infiltration. The Erinpura Granite in Sirohi region is strongly foliated with large K-feldspar porphyroblasts (up to few $\mathrm{cm}$ in size) and thus classified as granitegneiss. In the vicinity of the shear zone, the granite-gneiss is significantly altered. Locally, this alteration has obliterated the characteristic fabric of Erinpura Granite (figure 4) and has also resulted in significant reduction in GR activity $(163.54 \mathrm{nSv} / \mathrm{h})$ in altered granite in contrast to $175.56 \mathrm{nSv} / \mathrm{h}$ in non-altered parts. This can be attributed to the depletion of $\mathrm{K}$ and Th (table 2). In contrast, the $U$ content is enhanced in these altered parts of Erinpura Granite (5.34 ppm) as compared to the mean value calculated from 23 sites away from the BPSZ (4.18 ppm).

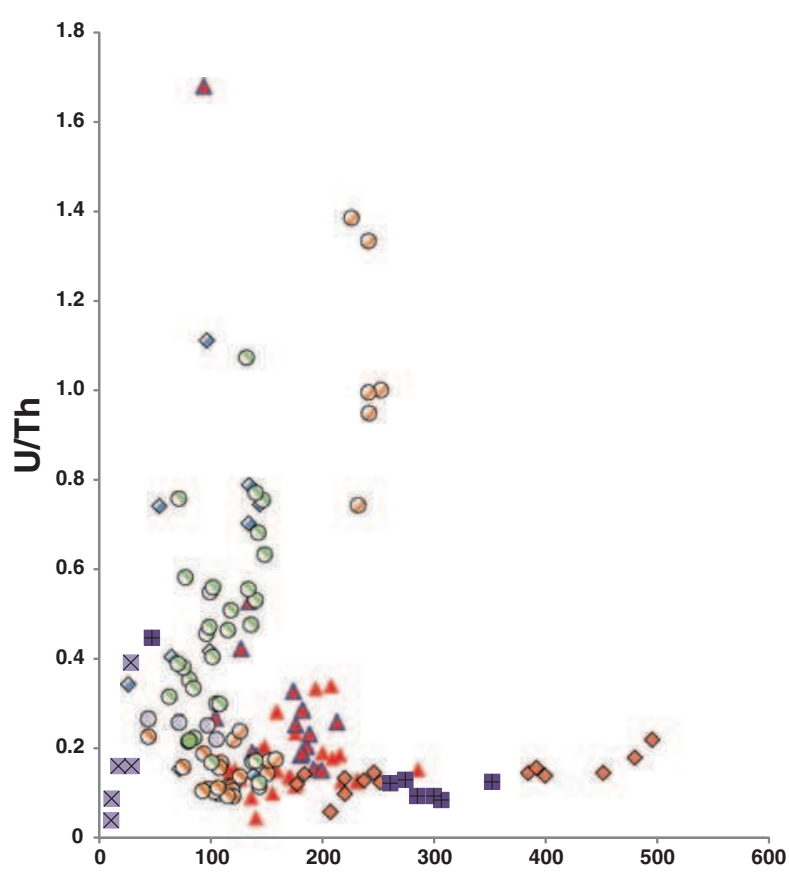

(a) radiation dose in $\mathrm{nSv} / \mathrm{h}$

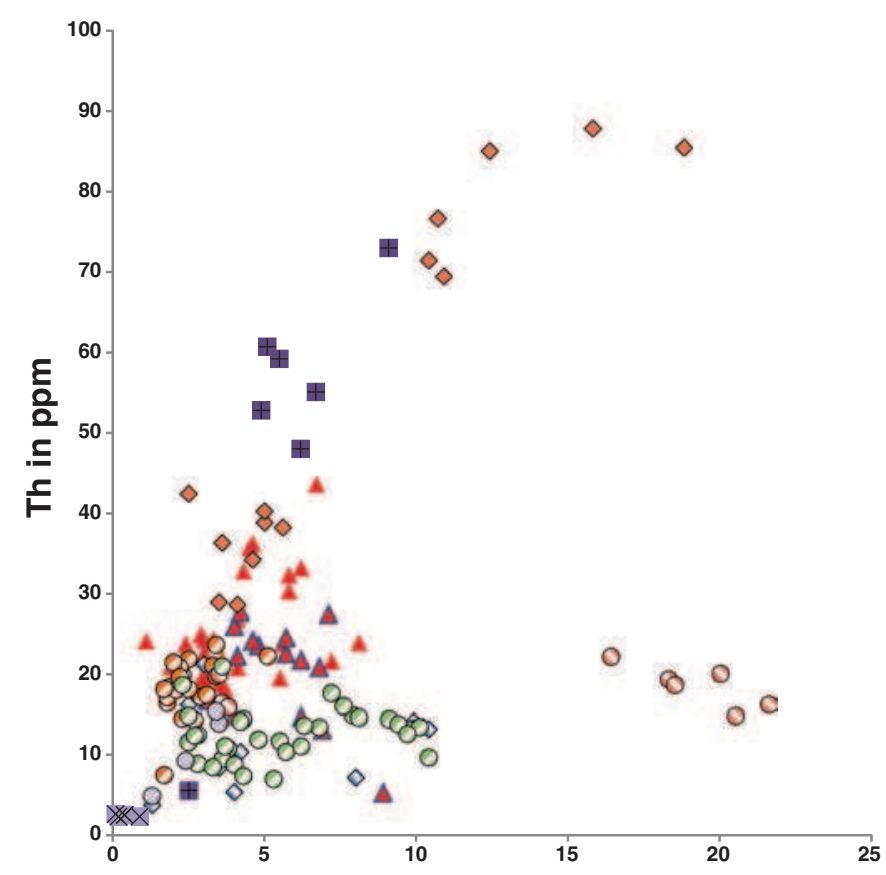

(b)

\section{$\mathbf{U}$ in ppm}

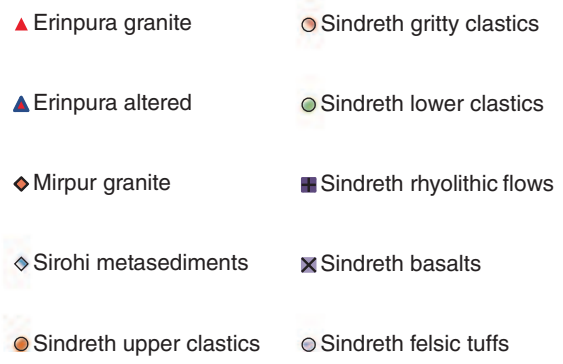

Figure 3. GR characteristics of rock units; (a) U/Th ratio vs. radiation dose and (b) U vs. Th. 

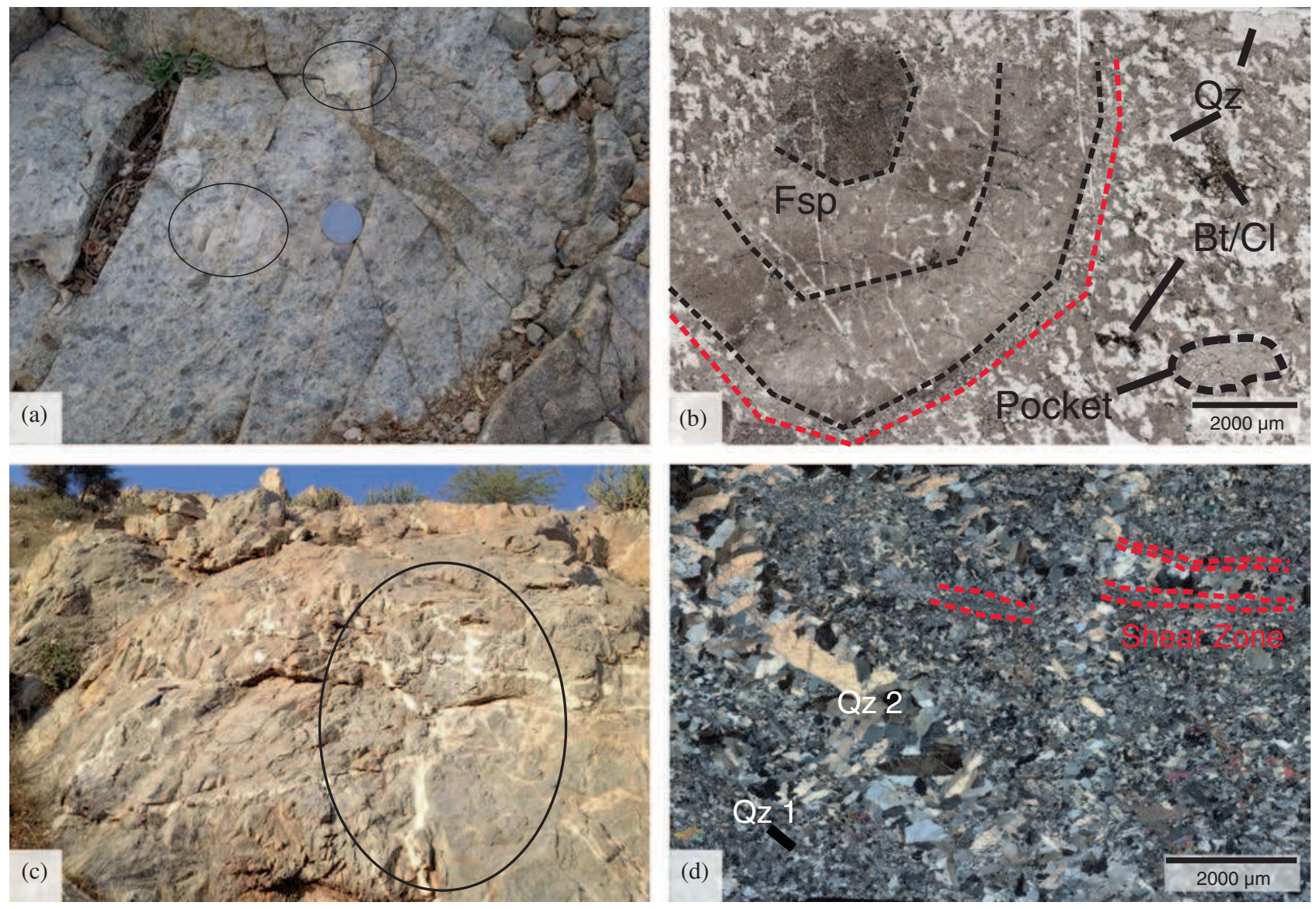

Figure 4. Features of alteration in Erinpura Granite due to fluid infiltration. (a) Erinpura Granite with large feldspar porphyroblasts (see black markings); (b) thin section analysis reveals the significant alteration of feldspar, photomicrograph with plane polars (black markings denote minerals, the red line denotes the border of the altered zone); (c) fluid infiltration into wall rocks with hydraulic fracturing (marked with a black circle), (d) photomicrograph of fluid infiltrated Erinpura Granite (c) shows quartz microveins cross-cutting the ductile shear foliation (red lines).

The change in GR spectra was also evaluated in a profile in a river section across the BPSZ with well exposed Balda Granite in the west and Erinpura Granite in the east (figure 5). These two granites of diverse age and geological settings show characteristic geochemical differences (Naik 1993), also reflected in differences in $\mathrm{U}$ and Th contents. This is also confirmed by laboratory analyses (de Wall et al. 2014) which show $14 \mathrm{ppm}$ Th in the Balda Granite and significantly high values (33 ppm) in the Erinpura Granite. The U content is generally higher in the Balda Granite (6 ppm) as compared to Erinpura Granite (3 ppm). The geochemical data are in agreement with the in situ measurements, which also show relatively higher Th values in Erinpura Granite samples, away from the BPSZ and thus reflect primary characteristics of the BPSZ wall rocks. Our preliminary in situ measurements indicate mobilization of $\mathrm{U}$ in Balda Granite close to the quartz reef (figure 5). The GR signals indicate $\mathrm{U}$ depletion away from the quartz reef and enrichment close to it. The Balda Granite shows low $\mathrm{U}$ values at the contact with the quartz reef.
It was observed that quartz veins are intercalated with the granite which might have lowered the U signals. Alteration of the Balda Granite by fluid activity along the BPSZ is also visible on a microscale. The impact of fluid infiltration is best seen in cathodoluminescence (CL) images which document a strong feldspar alteration (albitization) related to a network of fractures (figure 6).

\subsection{The Sindreth uranium anomaly}

The U anomaly reported from southern part of Sindreth Basin Group by Somani et al. (2012) was evaluated in more detail to get better constraints on the geological context of $U$ mobilization and accumulation. The GR measurements in this area were done across the entire stratigraphic sequence covering the coarse-grained clastics followed by gritty clastics as the uppermost stratigraphic member of the lower clastic unit. Mean $\mathrm{GR}_{\text {total }}$ in this gritty lithology is distinctly higher compared to the underlying coarse-grained clastics (table 2). Occasionally, values could reach more than $252.8 \mathrm{nSv} / \mathrm{h}$. 


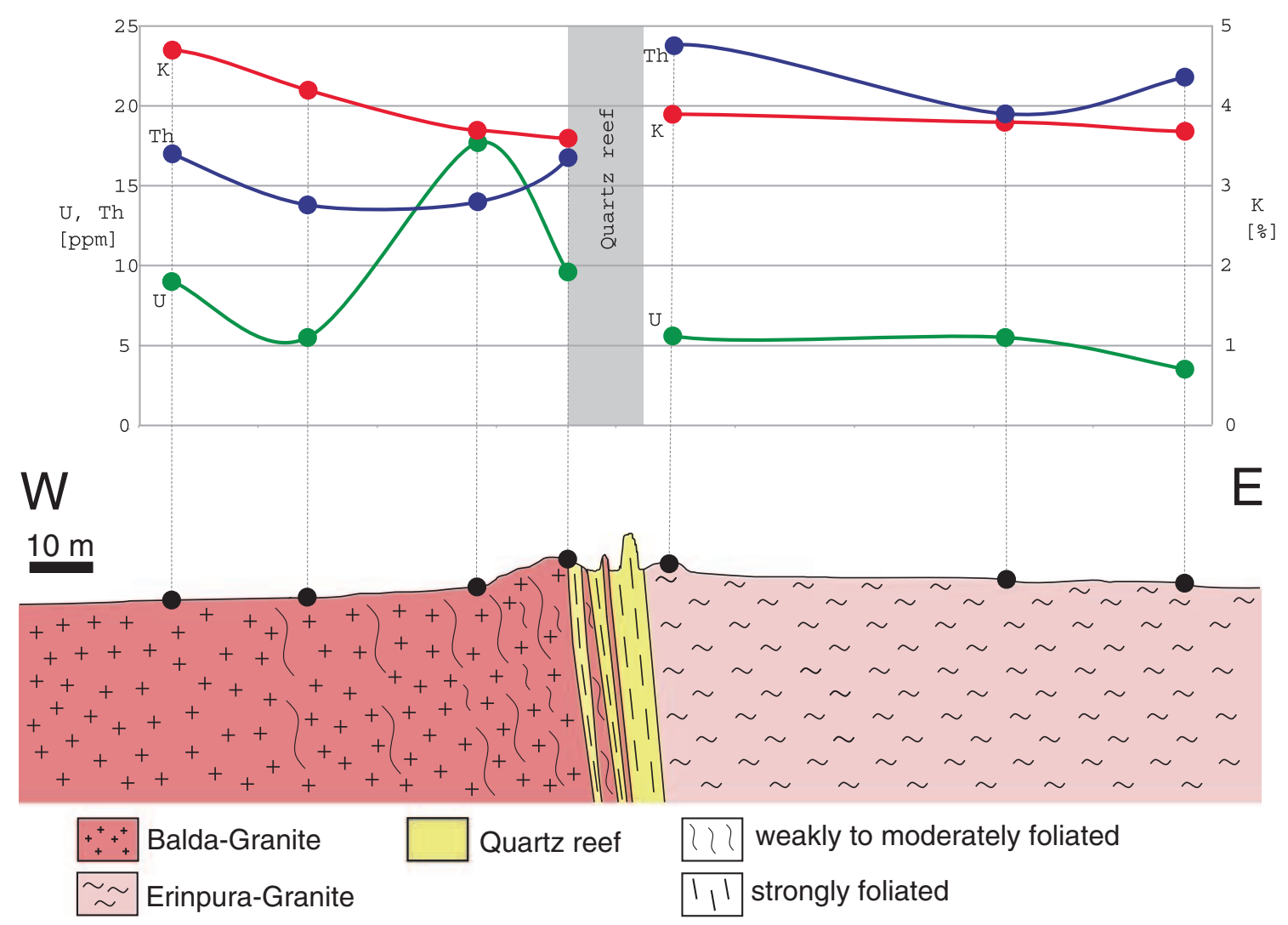

Figure 5. Section across the BPSZ exposed in a river section, for location, see figure 1.

While Th and $\mathrm{K}$ are almost constant in this gritty unit, $\mathrm{U}$ is highly variable and ranges from 3.4 to $21.6 \mathrm{ppm}$, pointing towards secondary enrichment after deposition of the gritty clastics.

Tectonic inversion within high crustal level has tilted the Sindreth Basin and has also resulted in development of a steep N-S trending fault zone west of Sindreth village. Segments of this fault are located within the lower clastic unit as well as between clastics and volcanics. These faults are exposed in the southern and central sectors of Sindreth Basin, while their northern continuation is covered under alluvium. Measurements along these faults yielded slightly enhanced $U$ values with a mean of around $5.44 \mathrm{ppm}$ (highest values of 10.4 $\mathrm{ppm}$ ) in contrast to $3.89 \mathrm{ppm}$ in the surrounding conglomerates, whereby U-enrichment is prominent along planes coated with a cm-thick limonitic encrustations (figure 7). Although increase in $\mathrm{U}$ is not very pronounced, the local $U$ enrichment could be much higher as the GR measurements integrate over a large volume and the coating is limited to individual planes.

\section{Discussion and interpretation}

This study has shown a strong variability in GR activity in Sirohi region that can be explained in the geological context. The initial $\mathrm{U} / \mathrm{Th}$ ratio in granitoids is quite variable due to differences in source composition, melting and crystallization conditions which is also reflected in the wide range of values for granites (table 2). Mirpur Granite and Sindreth rhyolite, as part of the Malani Igneous Suite, are characterized by high GR activity related to high Th content and low U/Th ratio. High Th content is a characteristic feature of high temperature melts which have formed the felsic rocks of the MIS, also seen in high concentrations of HFS elements such as Zr, Y, Nb and LREE (Eby and Kochhar 1990; de Wall et al. 2012) defining the MIS volcano-plutonic rocks as high heat-producing rocks (Singh and Vallinayagam 2012). Our in situ measurements have shown that these felsic rocks show an almost constant $\mathrm{U} / \mathrm{Th}$ ratio of 0.14 for the granite (Mirpur Granite) and 0.11 for the rhyolites. Their strong variation in total GR activity is most likely related to primary variation in abundance of $\mathrm{U}$ and Th-bearing minerals such as zircon and monazite. In contrast, the Erinpura and Balda granites are characterized by lower GR activity but slightly higher U/Th ratios. Both are S-type granites that can show a wide variability in $\mathrm{U}$ and Th contents in relation to the degree of magmatic differentiation (Hecht et al. 1997; Förster and Förster 2000).

Granites, felsic dykes and metasediments of the Sirohi region are the potential candidates as source 

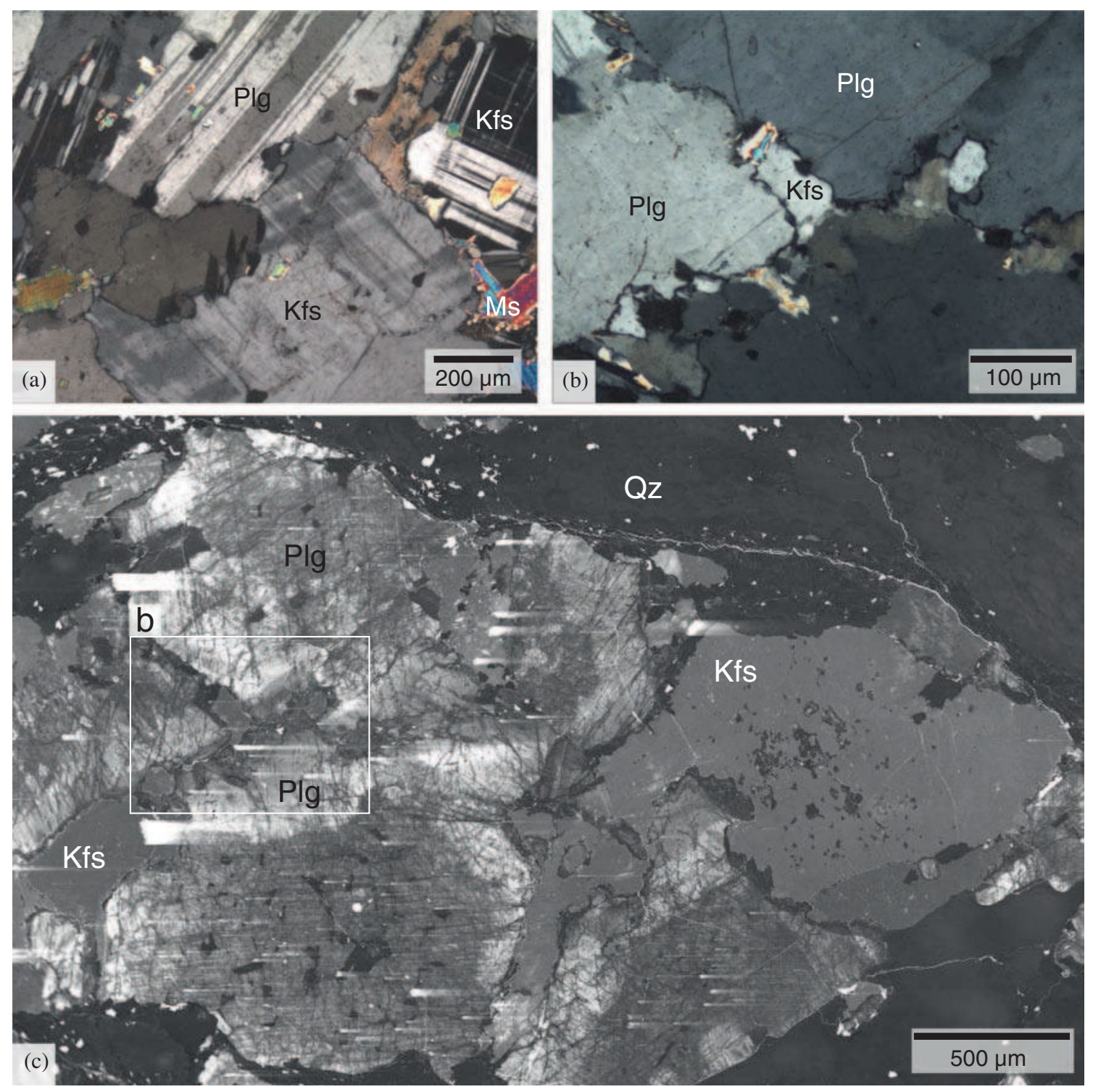

Figure 6. Evidence for fluid infiltration into the Balda granite: (a) Optical image (crossed polars) of unaffected Balda granite fabric in distance to the BPSZ; (b) optical image of granite fabrics closer to the BPSZ (sample is located between 392 and 393, see figure 4). The fractured nature of plagioclase is only visible in CL images (c). Variable sets of microfractures indicate formation under high fluid pressure. For comparison, the area of photomicrograph as shown in (b) is indicated.

rocks for the Sindreth clastics. The coarse grain size and unsorted nature of Sindreth sediments supports a near source deposition. Strong variation in initial $\mathrm{U} / \mathrm{Th}$ ratio of the source rocks is also reflected in the signals of the Sindreth clastics. There are clear differences in total GR as well as $\mathrm{U} / \mathrm{Th}$ ratios for the lower and upper clastic units (figure $3 \mathrm{a}, \mathrm{b}$ ), reflecting the change in provenance during the depositional history of the Sindreth Basin. The upper clastic sedimentary sequence in the Sindreth Basin shows U/Th ratios comparable to the Mirpur Granite and rhyolitic dykes therein. This calls for macroscopic and microscopic clast analyses that indicate substantial input from Malani granites and rhyolites. In the lower clastic units (coarse-grained and gritty parts), the measured sites can be discriminated into two different patterns in relation to their $U$ vs. total activity signatures (figure 8). Sites with $<5$ ppm U show a variable range in activity without any correlation between the two parameters, while sites with higher $U$ content show a linear relationship indicating a significant contribution of $U$ to the total signal.

The differences in $\mathrm{U} / \mathrm{Th}$ ratio can also be considered as an indication for the mobilization of uranium as stated earlier by Somani et al. (2012), because faults and shear zones in these units may have served as weak zones where mobilization by hydrothermal fluids has taken place. Such higher U-content in the Sindreth region has been proposed as volcanogenic-type U-mineralization related to 

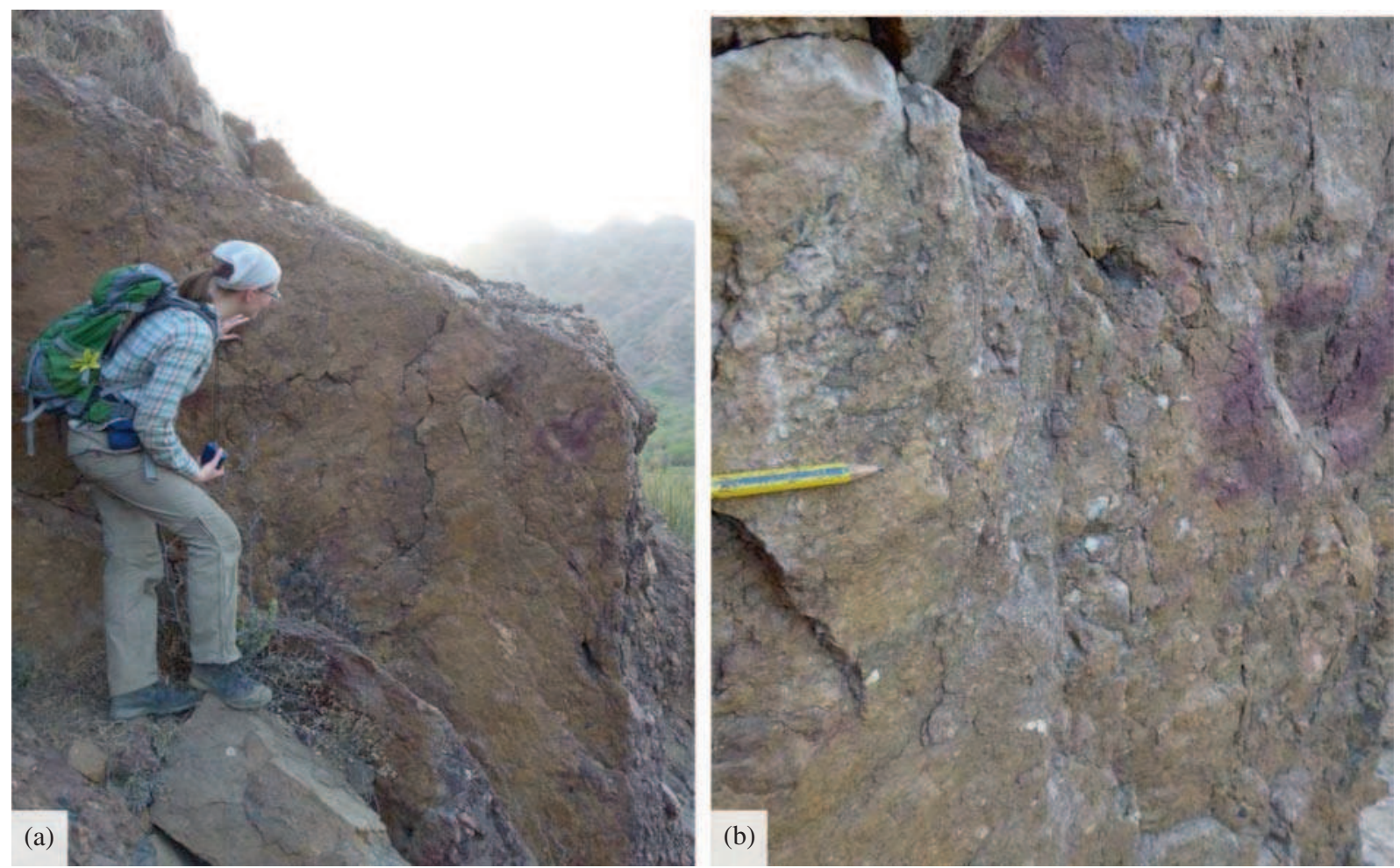

Figure 7. (a) Steep faults within the lower clastic unit in the eastern sector of the Sindreth Basin and (b) close-up of figure (a) shows the coating of the fault planes with ironhydroxide.

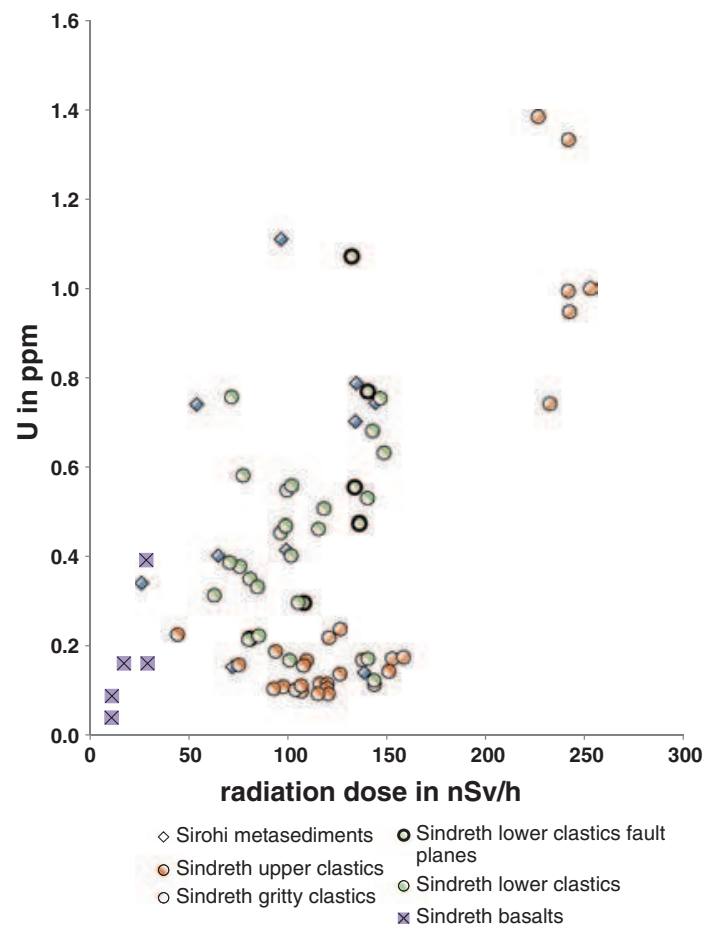

Figure 8. U in enrichment within lower clastic units confined to gritty clastics and fault planes in clastic units.

the bimodal volcanism and identified as a prospective target for uranium exploration in Rajasthan (Somani et al. 2012). In such a scenario, the U is released during devitrification of glassy components in felsic rocks (Rosholt and Noble 1971). Another potential uranium source could be the carbonaceous phyllite with higher inherent $\mathrm{U}$ content. However, for $\mathrm{U}$ transportation, a change from $\mathrm{U}^{+4}$ to $\mathrm{U}^{+6}$ is essential which can be brought about by oxidizing fluids such as the silica-rich fluids released during late stages of intrusion of felsic dykes into the Sindreth setting. Field observations offer evidence that the tectonic grain (steep foliation planes, fault zone) was already established prior to intrusion of felsic dykes into the lower clastic units. Percolation of silicic fluids along brittle fault zones and migration within the more permeable gritty parts seems a most likely scenario in this context. Uranium is generally leached and transported as $\mathrm{UO}_{2}^{+2}$, deoxidized as $\mathrm{U}^{+4}$ and accumulated as $\mathrm{UO}_{2}$ with precipitation generally occurring at geochemical barriers. This situation could be realized along the contact of the lower clastic units with the mafic rocks (volcanoclastics and basalts).

A first evaluation of $U$ mobility along the BPSZ has given indication for $\mathrm{U}$ enrichment in the Balda Granite in close vicinity of the shear zone. In contrast to the high crustal level with brittle faults in the Sindreth Basin, the BPSZ was formed at deeper crustal setting under high-pore fluid pressure. Silicic fluids migrated within the Sirohi metasediments and Erinpura Granite along the channel ways defined by the shear zones. As evident from 
deformation fabrics of the synkinematic quartz mineralization, the temperatures must have been higher than $300^{\circ} \mathrm{C}$. Leaching and transport of $\mathrm{U}$ by hydrothermal fluids is a well-known phenomenon in granitic terranes (e.g., Tartese et al. 2013).

\section{Conclusions}

GR mapping in the Sirohi region has provided useful information about distribution pattern of radioactive elements in the various rock units. The observed differences correlate well with the geological context. The measured $\mathrm{U} / \mathrm{Th}$ ratio provides information about primary characteristics of the rock types and secondary mobilization of nuclear elements. Granites and rhyolites of the Malani Igneous Suite show the highest GR activity, contributed mainly by a high content of Th-bearing minerals as part of the primary mineral assemblage. There are some areas of U enrichment in Sirohi region, such as the ductile BPSZ and the fault zones along the eastern margin of Sindreth Basin. It has been shown in the preceding sections that the high temperature fluids moving along the fault and shear system also facilitated transportation and redeposition of uranium. This preliminary analysis has shown that in situ measurements bear a great potential for identification of radiation anomalies. The detected enrichment of $U$ along shear and fault zones in the Sirohi-Sindreth regions requires a more detailed investigation.

\section{Acknowledgements}

We thank T Böhm, I Donhauser and T Hörbrand for their support in the field, and Richard Issa and Tom Cox from Radiation Solutions Inc., Canada and Tom Brunclik and Jaromir Babacek of GeoRadis, Czech Republic for providing technical details of the RS 230 spectrometer and explanations on data analysis. S Roy and an anonymous reviewer are thanked for their valuable and constructive comments.

\section{References}

Asfahani J, Al-Hent R and Aissa M 2012 Radioactive and geological analysis of airborne gamma spectrometric data for locating favourable traps for uranium prospecting in the Syrian desert (Area-1), Syria; Applied Radiation and Isotopes $\mathbf{7 0} 2317-2327$.

Aydin I, Aydogan M S, Oksm E and Koçak A 2006 An attempt to use aerial gamma-ray spectrometry results in petrochemical associations of Central Anatolia (Turkey); Geophysical J. Int. 67 1044-1052.

Bellotti E, Di Carlo G, Di Sabatino D, Ferrari N, Laubenstein M, Pandola L and Tomei C 2007 y-Ray spectrometry of soil samples from the Provincia dell'Aquila
(Central Italy); Applied Radiation and Isotopes 65 858865.

Bhowmik S K, Bernhardt H-J and Dasgupta S 2010 Grenvillian age high-pressure upper amphibolite-granulite metamorphism in the Aravalli-Delhi Mobile Belt, northwestern India: New evidence from monazite chemical age and its implication; Precamb. Res. 178 168-184.

Bhushan S K 2000 Malani rhyolites - a review; Gondwana Res. 3 65-77.

Chore S A and Mohanty M 1998 Stratigraphic and tectonic setting of the trans-Aravalli Neoproterozoic volcanosedimentary sequences in Rajasthan; J. Geol. Soc. India $\mathbf{5 1}$ 57-68.

de Wall H, Pandit M K, Dotzler R and Just J 2012 Cryogenian transpression and granite intrusion along the western margin of Rodinia (Mt. Abu region): Magnetic fabric and geochemical inferences on Neoproterozoic geodynamics of the NW Indian block; Tectonophys. 554-557 143-158.

de Wall H, Pandit M K, Sharma K K, Schöbel S and Just J 2014 Deformation and granite intrusion in the Sirohi area, SW Rajasthan - constraints on Cryogenian to PanAfrican crustal dynamics of NW India; Precamb. Res. 254 $1-18$.

Deb M, Thorpe R I, Krstic D, Corfu F and Davis D W 2001 Zircon $\mathrm{U}-\mathrm{Pb}$ and galena $\mathrm{Pb}$ isotope evidence for an approximate 1.0 Gaterrane constituting the western margin of the Aravalli-Delhi orogenic belt, north-western India; Precamb. Res. 108 195-213.

Eby G N and Kochhar N 1990 Geochemistry and Petrogenesis of the Malani Igneous Suite, north peninsular India; J. Geol. Soc. India 36 109-130.

El-Sadek M A 2002 Application of thorium-normalised airborne radio-spectrometric survey data of Wadi Araba area, north-eastern desert, Egypt, as a guide to the recognition of probable subsurface petroleum accumulations; Applied Radiation and Isotopes 57 121-130.

Förster A and Förster H-J 2000 Crustal composition and mantle heat flow: Implications from surface heat flow and radiogenic heat production in the Variscan Erzgebirge (Germany); J. Geophys. Res. 105 B12 27,917-27,938.

Grasty R L, Holman P B and Blanchard Y B 1991 Transportable calibration pads for ground and airborne gamma-ray spectrometers; Geological Survey of Canada Paper 90-23.

Gregory L C, Meert J G, Bingen B, Pandit M K and Torsvik T H 2009 Paleomagnetism and geochronology of the Malani Igneous Suite, northwest India: Implications for the configuration of Rodinia and the assembly of Gondwana; Precamb. Res. 170 13-26.

Gupta S N, Arora Y K, Mathur R K, Iqballuddin, Prasad B, Sahai T N and Sharma S B 1997 The Precambrian geology of the Aravalli region, southern Rajasthan and northeastern Gujarat; Geol. Surv. India Memoir 123 262p.

Hecht L, Vigneresse J L and Morteani G 1997 Constraints on the origin of zonation of the granite complexes in the Fichtelgebirge (Germany and Czech Republic): Evidence from a gravity and geochemical study; Geologische Rundschau 86 S93-S109.

Heron A M 1953 Geology of Central Rajputana; Geol. Surv. India Memoir 79 339p.

IAEA 2003 Guidelines for radioelement mapping using gamma ray spectrometry data. IAEA-TECDOC-1363, International Atomic Energy Agency, Wien.

Just J, Schulz B, de Wall H, Jourdan F and Pandit M K 2011 Monazite CHIME/EPMA dating of granitoid deformation: Implications for Neoproterozoic tectonothermal evolution of NW India; Gondwana Res. 19 $402-412$. 
Kochhar N 1989 High heat producing granites of the Malani Igneous suite, northern peninsular India; Indian Minerals 43 339-346.

Kovačević J, Nikić Z and Papić P 2009 Genetic model of uranium mineralization in the Permo-Triassic sedimentary rocks of the Stara Platanina eastern Serbia; Sedim. Geol. 219 252-261.

Kovačević J, Tereesh B M, Radenković M B and Miljanić S 2013 Discovery of uranium mineralization in the rhyolitegranite complex in the Jabal Eghei area of southern Libya; J. Serbian Chem. Soc. 78 741-758.

Meert J G, Pandit M K, Pradhan V R, Banks J, Sirianni R, Stroud M, Newstead B and Gifford J 2010 Precambrian crustal evolution of Peninsular India: A 3.0 billion year odyssey; J. Earth Syst. Sci. 39(6) 483-515.

Minor A 2013 Kinematic studies on the Late Neoproterozoic Balda-Paladi Shear Zone and associated quartz mineralisation, Sirohi region, NW India; Masters Dissertation, University of Erlangen-Nuremberg, Germany, $100 p$.

Naik M S 1993 The geochemistry and genesis of the granitoids of Sirohi, Rajasthan, India; J. Southeast Asian Earth Sci. 8 111-115.

Pandit M K, de Wall H, Daxberger H, Just J, Bestmann M and Sharma K K 2011 Mafic rocks from Erinpura gneiss terrane in the Sirohi region: Possible ocean floor remnants in the foreland of the Delhi Fold Belt, NW India; J. Earth Syst. Sci. 127 627-641.

Purohit R, Papineau D, Kröner A, Sharma K K and Roy A B 2012 Carbon isotope geochemistry and geochronological constraints of the Neoproterozoic Sirohi Group from northwest India; Precamb. Res. 220-221 8090.

Radiation Solutions Inc. 2007 RS-125 Assay Analysis comments re Precision (Preliminary). Technical Note 2007-1251 - Rev 1.

Rosholt J N and Noble D C 1971 Mobility of uranium and thorium in glassy and crystallized silicic volcanic rocks; Econ. Geol. 66 1061-1069.
Roy A B and Sharma K K 1999 Geology of the region around Sirohi town, western Rajasthan - story of Neoproterozoic evolution of the Trans-Aravalli crust; In: Geological Evolution of Western Rajasthan (ed.) Paliwal B S, Scientific Publishers (India), Jodhpur, pp. 19-33.

Schöbel S 2009 Magnetic fabric studies in Neoproterozoic granites of the Malani Igneous Suite, NW-India. Unpublished Diploma thesis, University of Würzburg, Germany, $78 \mathrm{p}$.

Sharma K K 1996 Stratigraphy, structure and tectonic evolution of the metasediments and associated rocks of the Sirohi region; Unpublished Ph.D. thesis, MLS University, Udaipur, 103p.

Sharma K K 2004 The Neoproterozoic Malani magmatism of the northwestern Indian shield: Implications for crustbuilding processes; Proc. Indian Acad. Sci. (Earth Planet. Sci.) 113(4) 795-807.

Singh L S and Vallinayagam G 2012 High heat producing volcano-plutonic rocks of the Siner area, Malani Igneous Suite, Western Rajasthan, India; Int. J. Geosci. 3 11371141.

Somani O P, Arpan Misra Jeyagopal A V, Nanda L K and Parihar P S 2012 Radioelement distribution in Neoproterozoic volcano-sedimentary Sindreth Basin, Sirohi District, Rajasthan and its significance; Curr. Sci. 103 305-309.

Tartese R, Boulvais P, Poujol M, Gloaguen E and Cuney M 2013 Uranium mobilization from the Variscan Questembert syntectonic granite during fluid-rock interaction at depth; Econ. Geol. 108 379-386.

Tzortzis M, Haralabos T, Christofides S and Christodoulides G 2003 Gamma-ray measurements of naturally occurring radioactive samples from Cyprus characteristic geological rocks; Radiation Measurements 37 221-229.

van Lente B, Ashwal L D, Pandit M K, Bowring S A and Torsvik T H 2009 Neoproterozoic hydrothermally altered basaltic rocks from Rajasthan, northwest India: Implications for late Precambrian tectonic evolution of the Aravalli craton; Precamb. Res. 170 202-222. 